\title{
Overgrazing induces alterations in the hepatic proteome of sheep (Ovis aries): an iTRAQ-based quantitative proteomic analysis
}

Weibo Ren ${ }^{1}$, Xiangyang Hou', Yuqing Wang ${ }^{1}$, Warwick Badgery ${ }^{2}$, Xiliang Li ${ }^{1}$, Yong Ding ${ }^{1}$, Huiqin Guo ${ }^{3}$, Zinian Wu', Ningning $\mathrm{Hu}^{1}$, Lingqi Kong ${ }^{1}$, Chun Chang ${ }^{1}$, Chao Jiang ${ }^{1}$ and Jize Zhang ${ }^{1 *}$

\begin{abstract}
Background: The degradation of the steppe of Inner Mongolia, due to overgrazing, has resulted in ecosystem damage as well as extensive reductions in sheep production. The growth performance of sheep is greatly reduced because of overgrazing, which triggers massive economic losses every year. The liver is an essential organ that has very important roles in multiple functions, such as nutrient metabolism, immunity and others, which are closely related to animal growth. However, to our knowledge, no detailed studies have evaluated hepatic metabolism adaption in sheep due to overgrazing. The molecular mechanisms that underlie these effects remain unclear.

Methods: In the present study, our group applied isobaric tags for relative and absolute quantitation (iTRAQ)-based quantitative proteomic analysis to investigate changes in the protein profiles of sheep hepatic tissues when nutrition was reduced due to overgrazing (12.0 sheep/ha), with the goal of characterizing the molecular mechanisms of hepatic metabolism adaption in sheep in an overgrazing condition.

Results: The body weight daily gain of sheep was greatly decreased due to overgrazing. Overall, 41 proteins were found to be differentially abundant in the hepatic tissue between a light grazing group and an overgrazing group. Most of the differentially expressed proteins identified are involved in protein metabolism, transcriptional and translational regulation, and immune response. In particular, the altered abundance of kynureninase (KYNU) and HAL (histidine ammonia-lyase) involved in protein metabolic function, integrated with the changes of serum levels of blood urea nitrogen (BUN) and glucose (GLU), suggest that overgrazing triggers a shift in energy resources from carbohydrates to proteins, causing poorer nitrogen utilization efficiency. Altogether, these results suggest that the reductions in animal growth induced by overgrazing are associated with liver proteomic changes, especially the proteins involved in nitrogen compounds metabolism and immunity.
\end{abstract}

Conclusions: This provides new information that can be used for nutritional supplementation to improve the growth performance of sheep in an overgrazing condition.

Keywords: Overgrazing, Liver, proteomics, Sheep

\footnotetext{
*Correspondence: jzz2006@126.com

'Key Laboratory of Forage Grass, Ministry of Agriculture, Institute of Grassland

Research, Chinese Academy of Agricultural Sciences, Hohhot 010010, Inner

Mongolia, China

Full list of author information is available at the end of the article
}

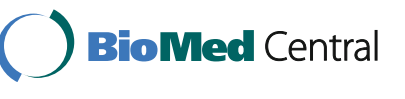

(c) The Author(s). 2017 Open Access This article is distributed under the terms of the Creative Commons Attribution 4.0 International License (http://creativecommons.org/licenses/by/4.0/), which permits unrestricted use, distribution, and reproduction in any medium, provided you give appropriate credit to the original author(s) and the source, provide a link to the Creative Commons license, and indicate if changes were made. The Creative Commons Public Domain Dedication waiver (http://creativecommons.org/publicdomain/zero/1.0/) applies to the data made available in this article, unless otherwise stated. 


\section{Background}

The Inner Mongolian steppe is the most important region for mutton and milk production in China [1]. However, this natural grassland has been severely damaged by overgrazing in recent decades [2]. The degradation of the Inner Mongolian steppe due to overgrazing also damages the ecosystem and has extensively reduced animal productions. Increasing evidence shows that the quantity and quality of herbage and growth of sheep were substantially reduced due to overgrazing $[3,4]$. Increasing grazing intensity elevated the odour source of volatile organic compounds in grassland plants and altered the morphological response of the host plants [5]. A previous study demonstrated that stocking rate rather than management system determined the ecological sustainability of pastoral livestock system [6]. Most importantly, the body weight gain was significantly decreased (up to 55\%) due to overgrazing during the grazing season in multiple years studies [7, 8]. However, few studies have been conducted on the effects of overgrazing on the metabolic alterations related to sheep growth due to the research gap between animal nutritional metabolism and grazing $[9,10]$. Furthermore, the molecular mechanism of the growth reduction induced by overgrazing in sheep is unknown.

The liver plays a central role in the regulation of the metabolism of carbohydrates, proteins, lipids and other nutrients in animals. Additionally, the liver has multiple other physiological functions in the body including immune response, regulating inflammation and the removal of xenobiotics $[11,12]$. A previous gene array study on beef cows demonstrated marked hepatic responses to high or low grazing herbage allowances of native grasslands, including genes associated with glucogenesis, fatty acid oxidation, cell growth, DNA replication and transcription [13]. The proteomic profile of hepatic tissue in goats fed a high-grain diet demonstrated that an altered expression of hepatic proteins was related to amino acids metabolism [14]. To date, most studies on grazing animal have simply focused on body weight gain relating to intake based on the quality and quantity of herbage. However, few detailed studies have been conducted on the hepatic response to overgrazing in sheep.

Studies have shown lack of correlation between mRNA and protein expression abundance due to RNA editing and posttranslational modifications $[15,16]$. Thus, the elucidation of protein expression is more imperative [17]. Previous research demonstrated that changes in animal growth performance are closely related to alterations in the protein expression in the hepatic tissue $[18,19]$. A number of enzymes or functional proteins in the liver participate in physiological processes relevant to immunity, detoxification, nutrient metabolism, and others [20]. It is not practical to simultaneously measure all protein expressions of hepatic tissue using classical biotechnologies such as western blot, immunohistochemical staining or ELISA.

Thus, we hypothesized that overgrazing can confer negative effects on the hepatic protein expression. Therefore, the objective of this study was to identify and characterize candidate proteins that were differentially induced in the livers of sheep from an overgrazed pasture during the grazing season using a label-based iTRAQ procedure (isobaric tags for relative and absolute quantitation) followed by LC-MS/MS.

\section{Results}

Effect of overgrazing on herbage and animals

The herbage crude protein (CP) and acid detergent lignin (ADL) contents in the overgrazing (OG) group were 34.4 and $19.6 \%$ greater, respectively, than those in the light grazing (LG) group over the grazing period $(P=0.003$; $P=0.049)$. However, the gross energy and nitrogen free extract (NFE) contents were significantly decreased in the OG group than the LG group $(16.42 \pm 0.37 \mathrm{~kJ} / \mathrm{g}$ vs. $17.53 \pm 0.12 \mathrm{~kJ} / \mathrm{g}, P=0.008 ; 40.2 \pm 1.5 \mathrm{~g} / \mathrm{kg}$ vs. $46.9 \pm 4.2 \mathrm{~g} /$ $\mathrm{kg}, P=0.048)$. There was no significant effect of overgrazing on neutral detergent fibre (NDF) or acid detergent fibre (ADF). However, NDF tended to decrease in the OG group $(P=0.096)$. A full description of the effects of overgrazing on herbage and animal growth performance are given in Additional file 1: Table S1 and Table 1, respectively.

In this study, all sheep had similar body weights $(31.5 \pm 4.5 \mathrm{~kg})$ at the beginning of the grazing experiment. Throughout the experimental grazing period (total $90 \mathrm{~d}$ ), the OG sheep had a $21.4 \%$ reduction in daily weight gain $(27 \mathrm{~g})(P=0.042)$ and $14.0 \%$ reduction in carcass weight $(2.8 \mathrm{~kg})(P=0.047)$ (Table 1$)$. Additionally, two most important organ indices (calculated based on the weight of the spleen and liver) in the OG group were significantly lower than those in the LG group $(P=0.004 ; P=0.010)$ (Table 1 ).

Table 1 Effect of overgrazing on the growth and immune organ indexes of sheep

\begin{tabular}{llll}
\hline & \multicolumn{3}{l}{ Groups } \\
\cline { 2 - 4 } $\mathrm{LG}^{\mathrm{c}}$ & $\mathrm{OG}^{\mathrm{d}}$ & $P$ value \\
\hline Daily gain $(\mathrm{g})$ & $153 \pm 13^{\mathrm{a}}$ & $126 \pm 9^{\mathrm{b}}$ & 0.042 \\
Carcass weight cold $(\mathrm{kg})$ & $22.8 \pm 1.2^{\mathrm{a}}$ & $20.0 \pm 1.2^{\mathrm{b}}$ & 0.047 \\
Index of spleen $(\%)^{\mathrm{c}}$ & $0.43 \pm 0.02^{\mathrm{a}}$ & $0.34 \pm 0.03^{\mathrm{b}}$ & 0.004 \\
Index of liver $(\%)^{\mathrm{c}}$ & $3.36 \pm 0.11^{\mathrm{a}}$ & $2.98 \pm 0.03^{\mathrm{b}}$ & 0.010 \\
\hline
\end{tabular}

a, b Values within a row not sharing a common superscript letter indicate significant difference at $P<0.05$. Numbers are means \pm SD. (Daily gain: $n=12$ for LG, $n=48$ for OG; $n=3$ for indices of immune organs). Immune organ indexes were calculated as the ration of organ weight to body weight

c $L G$ light grazing

d $O G$ overgrazing 


\section{Effect of overgrazing on biochemical parameters of serum}

The effects of overgrazing on the biochemical parameters of serum in sheep are shown in Table 2. The alanine aminotransferase (ALT) and aspartate aminotransferase (AST) activities in serum were significantly increased in response to overgrazing compared with light grazing $(P=0.038 ; P=0.009)$. Furthermore, the serum concentration of blood urea nitrogen (BUN) was significantly higher in the OG group than in the LG group $(P=0.046)$. In contrast, the levels of total protein (TP), glucose (GLU), non-esterified fatty acid (NEFA) and insulin-like growth factor 1 (IGF-1) in the serum were significantly decreased in response to overgrazing compared with light grazing $(P=0.044 ; P=0.017$; $P=0.032 ; P=0.018$ ). However, the levels of triglyceride (TG) and cholesterol (CHOL) were similar between the two groups $(P>0.05)$.

\section{Identification and comparison of proteins of differential abundance}

Using iTRAQ analysis, a total of 27,287 peptide spectral matches were found, and 2,153 proteins were identified within the FDR (false discover rate) of $1 \%$ (Additional file 2: Table S2). Following the statistical analysis, 45 proteins were found to be differentially expressed in hepatic tissue between the LG and OG groups, with 8 being up-regulated and 37 downregulated (Additional file 3: Table S3).

Table 2 Effect of overgrazing on serum biochemical parameters of sheep

\begin{tabular}{lccc}
\hline & \multicolumn{3}{l}{ Groups } \\
\cline { 2 - 4 } & \multicolumn{1}{c}{$\mathrm{LG}^{\mathrm{c}}$} & \multicolumn{1}{c}{ OG $^{\mathrm{d}}$} & $P$ value \\
\hline ALT $(\mathrm{IU} / \mathrm{L})^{\mathrm{e}}$ & $20.73 \pm 9.41^{\mathrm{b}}$ & $45.97 \pm 10.86^{\mathrm{a}}$ & 0.038 \\
AST $(\mathrm{IU} / \mathrm{L})^{\mathrm{f}}$ & $164.93 \pm 28.94^{\mathrm{b}}$ & $386.37 \pm 75.32^{\mathrm{a}}$ & 0.009 \\
$\mathrm{TP}(\mathrm{mmol} / \mathrm{L})^{\mathrm{g}}$ & $73.03 \pm 4.05^{\mathrm{a}}$ & $64.23 \pm 3.32^{\mathrm{b}}$ & 0.044 \\
$\mathrm{BUN}(\mathrm{mmol} / \mathrm{L})^{\mathrm{h}}$ & $5.03 \pm 0.42^{\mathrm{b}}$ & $6.77 \pm 0.96^{\mathrm{a}}$ & 0.046 \\
$\mathrm{GLU}(\mathrm{mmol} / \mathrm{L})^{\mathrm{i}}$ & $7.80 \pm 0.72^{\mathrm{a}}$ & $5.71 \pm 0.58^{\mathrm{b}}$ & 0.017 \\
TG $(\mathrm{mmol} / \mathrm{L})^{j}$ & $0.36 \pm 0.06$ & $0.35 \pm 0.07$ & 0.835 \\
$\mathrm{CHOL}(\mu \mathrm{mol} / \mathrm{l})^{\mathrm{k}}$ & $1.88 \pm 0.84$ & $1.44 \pm 0.11$ & 0.417 \\
NEFA $(\mathrm{mmol} / \mathrm{L})^{\mathrm{l}}$ & $0.61 \pm 0.01^{\mathrm{a}}$ & $0.44 \pm 0.09^{\mathrm{b}}$ & 0.032 \\
IGF-1 $(\mathrm{ng} / \mathrm{mL})^{\mathrm{m}}$ & $30.76 \pm 4.01^{\mathrm{a}}$ & $21.56 \pm 4.18^{\mathrm{b}}$ & 0.018 \\
\hline
\end{tabular}

${ }^{\mathrm{a}, \mathrm{b}}$ Values within a column not sharing a common superscript letter indicate significant difference at $P<0.05$. Numbers are means \pm SD. $(n=6)$

c $L G$ light grazing

d $O G$ overgrazing

e $A L T$ alanine aminotransferase

${ }^{f}$ AST aspartate aminotransferase

${ }^{g}$ TP total protein

${ }^{\mathrm{h}}$ BUN blood urea nitrogen

i GLU glucose

j TG triglyceride

${ }^{k} \mathrm{CHOL}$ cholesterol

${ }^{\prime} N E F A$ non-esterified fatty acid

$\mathrm{m}$ IGF-1 insulin-like growth factor 1
A total of 41 proteins of differential abundance were grouped into nine classes based on putative functions: protein modification and metabolism (14.6\%), transcriptional and translational regulation (14.6\%), immune response, apoptosis and inflammation (14.6\%), energy metabolism (12.2\%), miscellaneous (12.2\%), lipid metabolism (9.8\%), stress response and detoxification (9.8\%), cell cytoskeleton (7.3\%) and cell growth and proliferation (4.9\%) (Fig. 1). Those related to protein modification and metabolism, transcriptional and translational regulation, immune response, apoptosis and inflammation, and energy metabolism were predominant and accounted for approximately $55 \%$ of the differentially-expressed proteins. A comparison of proteins of differential abundance with functional grouping between the two grazing intensities indicated that more protein species were down- regulated in the overgrazing sheep (34 versus 7, respectively) (Table 3). Most importantly, the protein species that participated in energy metabolism, lipid metabolism, cell cytoskeleton, and cell growth and proliferation were found to be down-regulated in OG sheep in the present study.

\section{GO annotations and pathway analysis}

In the cellular component group, the differentially expressed proteins are concentrated in the cell part and membrane-bounded organelle (Fig. 2). In the molecular functional group, the differentially expressed proteins that were binding proteins (protein binding, ion binding and heterocyclic compound binding), metabolic enzymes (hydrolase activity, transferase activity and oxidoreductase activity) and structural molecules (structural constituents of ribosomes) were ranked at the top of the category occupancy, suggesting that their related functions were important in the livers of the sheep (Fig. 2). In the biological process category, the proteins that participate in cellular processes (macromolecule metabolism), single-organism process and metabolism (nitrogen compound metabolism, heterocycle metabolism and lipid metabolism) were at the highest ratios among the differentially expressed proteins (Fig. 2), suggesting that overgrazing primarily results in changes to nutrient metabolism.

Furthermore, GO annotation and a KEGG pathway enrichment analysis were performed to determine the overrepresented biological events and to provide a primary overview of the hepatic proteome impacted by overgrazing. The DAVID 6.7 software identified highly overrepresented GO classes including cellular components, molecular functions and biological processes (Additional file 4: Table S4). For these identified differentially expressed proteins, the cellular component classifications were enriched in the cytoplasmic membrane-bounded vesicle, membranebounded vesicle, cytoplasmic vesicle and vesicle. According to the molecular function classifications, the differentially expressed proteins were enriched in vitamin binding, 


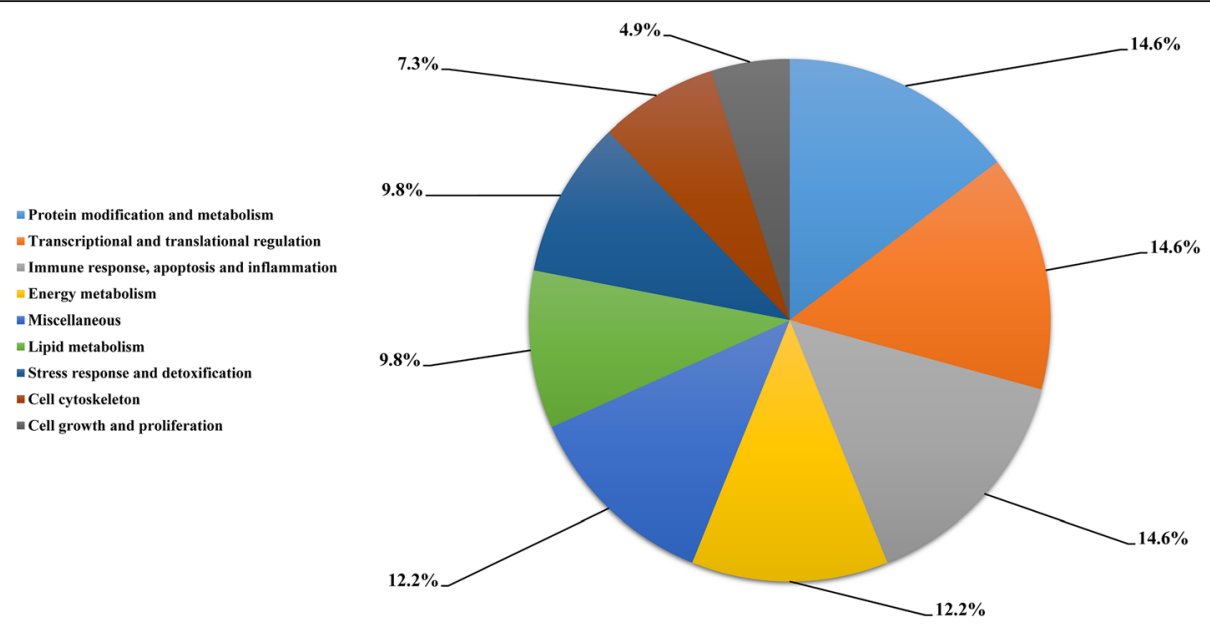

Fig. 1 Functional classification of the proteins of differential abundance identified from the hepatic tissues of sheep

cofactor binding, vitamin B6 binding and pyridoxal phosphate binding. Enriched biological process classifications of the differentially expressed proteins included the heterocycle catabolic process, response to unfolded proteins, the cellular amino acid catabolic process and response to protein stimulus, which implies that the protein metabolic process was greatly influenced in the livers of sheep in an overgrazing condition. A KEGG analysis showed that insulin signaling was significantly enriched $(P=0.047)$ in the identified pathways, which indicates that overgrazing had affected glucose and energy metabolism in the sheep.

\section{Target proteomics validation of important proteins of differential abundance}

Three differentially expressed proteins (KYNU involved in amino acid catabolism, FASN involved in fatty acids synthesis, and ARSD as disease marker) were selected for validation of proteomic data at the protein level using parallel reaction monitoring (PRM). The results of PRM analysis indicated that candidate proteins show similar trends as the iTRAQ results, which implied the credibility of the proteomics data (Fig. 3).

\section{Effect of overgrazing on immune response and inflammatory indexes of serum}

As shown in the list of differentially expressed protein species involved, those related to immune response and inflammation were ranked at one of the top putative protein functions. To further evaluate the effect of overgrazing on the immune response and inflammatory parameters of sheep, we measured the levels of primary immunoglobulins (Ig) and inflammatory cytokines in serum (Table 4). The levels of primary inflammatory cytokines, including interleukin-1 $\beta$ (IL-1 $\beta$ ), interleukin-4 (IL-4) and interleukin6 (IL-6), were greatly increased in the OG group compared with the LG group $(P=0.004 ; P=0.007 ; P=0.001)$. While, the levels of IgA, IgG and interferon- $\gamma$ (IFN- $\gamma$ ) were significantly lower in the OG group than in the LG group $(P=0.050 ; P=0.022 ; P=0.036)$.

\section{Discussion}

The liver is a vital organ that plays important roles in multiple physiological functions such as nutrient metabolism, detoxification, immune response and others. Any change in dietary components can be closely related to animal growth, which is reflected in variations of hepatic protein expressions in most cases. Whether overgrazing has a direct effect on the functional hepatocytes (thereby causing synthetic and metabolic changes in the sheep's liver) remains unclear. Substantially less is understood regarding the molecular mechanism of hepatic response in sheep with reduced nutrition due to overgrazing. In the present study, an iTRAQ-based quantitative proteomic analysis integrated with biochemical and immune analyses was applied to investigate the hepatic response in overgrazed sheep. When integrated with the proteomic profiles, biochemical and immune detections, these data suggest that overgrazing triggers a shift in energy resources from carbohydrates to proteins, which results in the impairment of nutrient metabolism (protein and lipid) and immunity, which may be the reasons for reduced growth in sheep.

Serum levels of ALT and AST serve as important indicators of hepatic health status and were found to be greatly elevated in OG sheep, indicating that overgrazing had a severely negative effect on hepatic function [21]. Additionally, a higher level of BUN in the serum of the OG group suggested that overgrazing was associated with poorer nitrogen utilization efficiency [22]. Furthermore, a decreased serum level of TP and an increased serum level of GLU in OG sheep during the period may have been caused by a shift in energy resources from carbohydrates to proteins 
Table 3 List of differentially expressed proteins in hepatic samples from overgrazing group and light grazing group

\begin{tabular}{|c|c|c|c|c|c|}
\hline Accession $^{a}$ & Description $^{b}$ & Gene symbol & Fold change & $p$-value & Biological process $\mathrm{GO}$ term \\
\hline \multicolumn{6}{|c|}{ Energy metabolism } \\
\hline W5NYL7 & $\begin{array}{l}\text { Uncharacterized protein OS = Ovis aries GN }= \\
\text { MTHFD1L PE }=3 \mathrm{SV}=1-[\text { W5NYL7_SHEEP] }\end{array}$ & MTHFD1L & 0.69 & 0.0403 & ATP binding \\
\hline Q5MIB6 & $\begin{array}{l}\text { Glycogen phosphorylase, brain form OS = Ovis } \\
\text { aries } G N=P Y G B P E=2 S V=3-\left[P Y G B \_S H E E P\right]\end{array}$ & PYGB & 0.82 & 0.0397 & Carbohydrate metabolic process \\
\hline W5PM30 & $\begin{array}{l}\text { Uncharacterized protein OS = Ovis aries GN = } \\
\text { CREB3L3 PE }=4 \mathrm{SV}=1-[\text { W5PM30_SHEEP] }\end{array}$ & CREB3L3 & 0.72 & 0.0223 & $\begin{array}{l}\text { Maintaining systemic energy } \\
\text { homeostasis }\end{array}$ \\
\hline W5NUJ4 & $\begin{array}{l}\text { Uncharacterized protein OS = Ovis aries GN }= \\
\text { NEK9 PE }=4 \mathrm{SV}=1-[\text { W5NUJ4_SHEEP }]\end{array}$ & NEK9 & 0.82 & 0.0185 & ATP binding \\
\hline B9VXW5 & $\begin{array}{l}\text { Mammalian target of rapamycin OS = Ovis } \\
\text { aries } \mathrm{PE}=2 \mathrm{SV}=1-[\mathrm{BPVXW} 5 \text { _SHEEP }]\end{array}$ & mTOR & 0.83 & 0.0051 & ATP binding \\
\hline \multicolumn{6}{|c|}{ Protein modification and metabolism } \\
\hline W5PJN6 & $\begin{array}{l}\text { Kynureninase OS = Ovis aries GN }=\text { KYNU } \\
\mathrm{PE}=3 \mathrm{SV}=1-\text { [W5PJN6_SHEEP] }\end{array}$ & KYNU & 1.21 & 0.0148 & Tryptophan catabolic process \\
\hline W5Q678 & $\begin{array}{l}\text { Uncharacterized protein OS = Ovis aries } \\
\mathrm{GN}=\mathrm{SEC} 24 \mathrm{D} P \mathrm{PE}=4 \mathrm{SV}=1-\left[\mathrm{W} 5 \mathrm{Q} 678 \_\mathrm{SHEEP}\right]\end{array}$ & SEC24D & 0.81 & 0.0369 & Intracellular protein transport \\
\hline W5QHW3 & $\begin{array}{l}\text { Uncharacterized protein OS = Ovis aries } \\
\mathrm{GN}=\mathrm{THNSL2} \mathrm{PE}=4 \mathrm{SV}=1-[\mathrm{W} 5 \mathrm{QHW} 3 \text { _SHEEP] }\end{array}$ & THNSL2 & 0.60 & 0.0349 & Serine binding \\
\hline W5PFC9 & $\begin{array}{l}\text { Uncharacterized protein (Fragment) OS = Ovis } \\
\text { aries GN }=\text { LOC101117129 PE }=4 \mathrm{SV}=1- \\
\text { [W5PFC9_SHEEP] }\end{array}$ & LOC101117129 & 0.78 & 0.0099 & Enzyme inhibitor activity \\
\hline W5QF53 & $\begin{array}{l}\text { Uncharacterized protein OS = Ovis aries GN }= \\
\text { ZFAND2B PE }=4 \mathrm{SV}=1-[\mathrm{W} 5 \mathrm{QF53} \text { _SHEEP] }\end{array}$ & ZFAND2B & 0.67 & 0.0095 & Maintain cellular folding capacity \\
\hline W5PRG9 & $\begin{array}{l}\text { Histidine ammonia-lyase OS = Ovis aries } \\
\mathrm{GN}=\mathrm{HAL} \mathrm{PE}=3 \mathrm{SV}=1-[\mathrm{W} 5 \mathrm{PRG} \text {.SHEEP] }\end{array}$ & HAL & 0.83 & 0.0062 & $\begin{array}{l}\text { Elimination of ammonia from the } \\
\text { substrate }\end{array}$ \\
\hline Accession $^{a}$ & Description ${ }^{\mathrm{b}}$ & Gene symbol & Fold change & $p$-value & Biological process $\mathrm{GO}$ term \\
\hline \multicolumn{6}{|c|}{ Lipid metabolism } \\
\hline W5PMR6 & $\begin{array}{l}\text { Uncharacterized protein OS = Ovis aries } \\
\mathrm{GN}=\text { DERL1 PE }=4 \mathrm{SV}=1-[\text { W5PMR6_SHEEP] }\end{array}$ & DERL1 & 0.73 & 0.0362 & ApoB secretion \\
\hline W5P8F9 & $\begin{array}{l}\text { Uncharacterized protein OS }=\text { Ovis aries } \\
\mathrm{PE}=4 \mathrm{SV}=1-[\mathrm{W} 5 \mathrm{P} 8 \mathrm{~F} 9 \text { SHEEP] }\end{array}$ & None & 0.74 & 0.0203 & Lipid binding \\
\hline W5PKK8 & $\begin{array}{l}\text { Uncharacterized protein OS = Ovis aries } \\
\mathrm{GN}=\mathrm{ESYT} 1 \mathrm{PE}=4 \mathrm{SV}=1-\text { [W5PKK8_SHEEP] }\end{array}$ & ESYT1 & 0.81 & 0.0344 & Lipid binding \\
\hline W5Q6U0 & $\begin{array}{l}\text { Uncharacterized protein OS = Ovis aries } \\
\text { GN }=\text { FASN PE }=4 \text { SV }=1-\text { [W5Q6UO_SHEEP] }\end{array}$ & FASN & 0.79 & 0.0147 & De novo synthesis of fatty acids \\
\hline \multicolumn{6}{|c|}{ Transcriptional and translational regulation } \\
\hline W5P328 & $\begin{array}{l}\text { Uncharacterized protein OS }=\text { Ovis aries } \\
\mathrm{GN}=\text { EIF2A PE }=4 \mathrm{SV}=1-\text { [W5P328_SHEEP] }\end{array}$ & EIF2A & 1.26 & 0.0487 & Regulation of translation \\
\hline W5P2A1 & $\begin{array}{l}\text { Uncharacterized protein OS }=\text { Ovis aries } \\
\mathrm{PE}=3 \mathrm{SV}=1-\left[\mathrm{W} 5 \mathrm{P} 2 \mathrm{~A} 1 \_\mathrm{SHEEP}\right]\end{array}$ & None & 0.81 & 0.0482 & Translational elongation \\
\hline W5PLU3 & $\begin{array}{l}\text { Uncharacterized protein OS = Ovis aries } \\
\mathrm{GN}=\mathrm{ZNF} 207 \mathrm{PE}=4 \mathrm{SV}=1-[\mathrm{W} 5 \mathrm{PLU3} \text { _SHEEP] }\end{array}$ & ZNF207 & 0.68 & 0.0389 & $\begin{array}{l}\text { Transcription regulation and } \\
\text { chromatin organization }\end{array}$ \\
\hline W5PHI1 & $\begin{array}{l}\text { Uncharacterized protein (Fragment) } \\
\text { OS }=\text { Ovis aries GN }=\text { MRPL3 PE }=3 \\
\text { SV }=1 \text { - [W5PHI1_SHEEP] }\end{array}$ & MRPL3 & 0.59 & 0.0325 & Structural constituent of ribosome \\
\hline W5PTA9 & $\begin{array}{l}\text { Uncharacterized protein OS = Ovis aries } \\
\mathrm{GN}=\mathrm{DCPS} \mathrm{PE}=4 \mathrm{SV}=1-\text { [W5PTA9_SHEEP }]\end{array}$ & DCPS & 0.69 & 0.0039 & Regulation of RNA stability \\
\hline BOFZMO & $\begin{array}{l}\text { Ribosomal protein L14-like protein } \\
\text { (Fragment) OS }=\text { Ovis aries PE }=2 \\
\mathrm{SV}=1-[\mathrm{BOFZZMOSHEEP}]\end{array}$ & None & 0.75 & 0.0028 & Structural constituent of ribosome \\
\hline Accession $^{\mathrm{a}}$ & Description $^{\mathrm{b}}$ & Gene symbol & Fold change & $p$-value & Biological process GO term \\
\hline \multicolumn{6}{|c|}{ Immune response, apoptosis and inflammation } \\
\hline W5QAE0 & & TMBIM6 & 1.31 & 0.0247 & \\
\hline
\end{tabular}


Table 3 List of differentially expressed proteins in hepatic samples from overgrazing group and light grazing group (Continued)

\begin{tabular}{|c|c|c|c|c|c|}
\hline & $\begin{array}{l}\text { Uncharacterized protein OS = Ovis aries } \\
\mathrm{GN}=\mathrm{TMBIM} 6 \mathrm{PE}=3 \mathrm{SV}=1-\text { [W5QAEO_SHEEP] }\end{array}$ & & & & $\begin{array}{l}\text { Intrinsic apoptotic signaling } \\
\text { pathway }\end{array}$ \\
\hline W5PKK4 & $\begin{array}{l}\text { Uncharacterized protein OS = Ovis aries } \\
\mathrm{GN}=\mathrm{CCAR2} \mathrm{PE}=4 \mathrm{SV}=1-\text { [W5PKK4_SHEEP] }\end{array}$ & CCAR2 & 1.51 & 0.0402 & $\begin{array}{l}\text { Positive regulation of apoptotic } \\
\text { process }\end{array}$ \\
\hline W5PUV3 & $\begin{array}{l}\text { Uncharacterized protein OS = Ovis aries } \\
\mathrm{GN}=\text { NT5E PE }=3 \mathrm{SV}=1-[\text { W5PUV3_SHEEP] }\end{array}$ & NT5E & 0.83 & 0.0387 & Marker of lymphocyte differentiation \\
\hline W5P8T5 & $\begin{array}{l}\text { Uncharacterized protein OS = Ovis aries } \\
\mathrm{GN}=\mathrm{PPM} 1 \mathrm{~B} \mathrm{PE}=3 \mathrm{SV}=1-\text { [W5P8T5_SHEEP] }\end{array}$ & PPM1B & 0.73 & 0.0358 & $\begin{array}{l}\text { Protein serine/threonine } \\
\text { phosphatase activity }\end{array}$ \\
\hline W5NZ57 & $\begin{array}{l}\text { Proteasome subunit beta type OS = Ovis } \\
\text { aries GN }=\text { PSMB10 PE }=3 \text { SV }=1-[\text { W5NZ57_SHEEP] }\end{array}$ & PSMB10 & 0.78 & 0.0344 & T cell proliferation \\
\hline W5Q0Z8 & $\begin{array}{l}\text { Uncharacterized protein OS = Ovis aries } \\
\text { GN }=\text { TRIM56 PE }=4 \text { SV }=1-[\text { W5Q0Z8_SHEEP] }\end{array}$ & TRIM56 & 0.29 & 0.0011 & Regulator of host innate immunity \\
\hline \multicolumn{6}{|c|}{ Stress response and detoxification } \\
\hline W5PGA7 & $\begin{array}{l}\text { UDP-glucuronosyltransferase OS = Ovis } \\
\text { aries GN }=\text { UGT2B7 PE }=3 \mathrm{SV}=1-\text { [W5PGA7_SHEEP] }\end{array}$ & UGT2B7 & 0.79 & 0.0376 & $\begin{array}{l}\text { Elimination of potentially toxic } \\
\text { xenobiotics and endogenous } \\
\text { compounds }\end{array}$ \\
\hline W5PWA2 & $\begin{array}{l}\text { Uncharacterized protein OS = Ovis aries } \\
\mathrm{PE}=3 \mathrm{SV}=1-[\mathrm{W} 5 \mathrm{PWA} 2 \text { SHEEP] }\end{array}$ & None & 1.24 & 0.0140 & Oxidoreductase activity \\
\hline W5PKE4 & $\begin{array}{l}\text { Uncharacterized protein OS = Ovis aries } \\
\mathrm{PE}=4 \mathrm{SV}=1-[\text { W5PKE4_SHEEP] }\end{array}$ & None & 0.56 & 0.0024 & Oxidation reduction process \\
\hline W5P214 & $\begin{array}{l}\text { Transgelin OS = Ovis aries GN = TAGLN } \\
\mathrm{PE}=3 \mathrm{SV}=1-\left[\mathrm{W} 5 \mathrm{P} 214 \_ \text {SHEEP] }\right.\end{array}$ & TAGLN & 0.82 & 0.0006 & Stress response related \\
\hline \multicolumn{6}{|c|}{ Cell growth and proliferation } \\
\hline W5Q8Q6 & $\begin{array}{l}\text { Uncharacterized protein OS = Ovis aries } \\
\mathrm{GN}=\mathrm{KANK} 2 \mathrm{PE}=4 \mathrm{SV}=1-[\mathrm{W} 5 \mathrm{Q} 8 \mathrm{Q} 6 \text { _SHEEP] }\end{array}$ & KANK2 & 0.81 & 0.0474 & Promotion of cell proliferation \\
\hline W5P0W0 & $\begin{array}{l}\text { Uncharacterized protein (Fragment) } \\
\text { OS }=\text { Ovis aries GN }=\text { IST1 } \mathrm{PE}=4 \\
\mathrm{SV}=1-\text { [W5POWO_SHEEP] }\end{array}$ & IST1 & 0.72 & 0.0015 & Cytokinesis \\
\hline Accession $^{a}$ & Description $^{b}$ & Gene symbol & Fold change & $p$-value & Biological process GO term \\
\hline \multicolumn{6}{|c|}{ Cell cytoskeleton } \\
\hline W5PK38 & $\begin{array}{l}\text { Uncharacterized protein (Fragment) } \\
\text { OS }=\text { Ovis aries GN }=\text { VASP PE }=4 \\
\text { SV }=1-[\text { W5PK38_SHEEP] }\end{array}$ & VASP & 0.76 & 0.0135 & Actin cytoskeleton organization \\
\hline W5Q5K3 & $\begin{array}{l}\text { Uncharacterized protein (Fragment) } \\
\text { OS }=\text { Ovis aries GN }=\text { NCKAP1 PE }=4 \\
\mathrm{SV}=1-[\text { W5Q5K3_SHEEP }]\end{array}$ & NCKAP1 & 0.69 & 0.0022 & Regulation of actin cytoskeleton \\
\hline W5Q8P7 & $\begin{array}{l}\text { Uncharacterized protein (Fragment) } \\
\text { OS }=\text { Ovis aries GN }=\text { SNTB1 PE }=4 \\
\mathrm{SV}=1-[\text { [W588P7_SHEEP] }\end{array}$ & SNTB1 & 0.59 & 0.0004 & Structural molecule activity \\
\hline \multicolumn{6}{|c|}{ Miscellaneous } \\
\hline W5PEV3 & $\begin{array}{l}\text { Uncharacterized protein OS }=\text { Ovis aries } \\
\mathrm{GN}=\mathrm{ARSD} P \mathrm{PE}=4 \mathrm{SV}=1-\left[\mathrm{W} 5 \mathrm{PEV} 3 \_\mathrm{SHEEP}\right]\end{array}$ & ARSD & 1.24 & 0.0138 & Disease marker \\
\hline W5NRU6 & $\begin{array}{l}\text { Uncharacterized protein OS = Ovis aries } \\
\mathrm{GN}=\mathrm{MYADM} P E=4 \mathrm{SV}=1-\text { [W5NRU6_SHEEP] }\end{array}$ & MYADM & 1.36 & 0.0102 & Disease marker \\
\hline W5QGB6 & $\begin{array}{l}\text { Uncharacterized protein OS = Ovis aries } \\
\mathrm{GN}=\mathrm{GCHFR} P \mathrm{PE}=4 \mathrm{SV}=1-\text { [W5QGB6_SHEEP] }\end{array}$ & GCHFR & 0.79 & 0.0386 & $\begin{array}{l}\text { Negative regulation of biosynthetic } \\
\text { process }\end{array}$ \\
\hline W5P2J9 & $\begin{array}{l}\text { Uncharacterized protein OS }=\text { Ovis aries } \\
\mathrm{PE}=3 \mathrm{SV}=1-[\text { W5P2J9_SHEEP] }\end{array}$ & RUSC1 & 0.77 & 0.0342 & Transferase activity \\
\hline W5PMB1 & $\begin{array}{l}\text { Uncharacterized protein OS = Ovis aries } \\
\mathrm{GN}=\mathrm{SNX} 3 \mathrm{PE}=4 \mathrm{SV}=1-[\mathrm{W} 5 \mathrm{PMB} 1 \text { SHEEP }]\end{array}$ & SNX3 & 0.82 & 0.0197 & Iron homeostasis \\
\hline
\end{tabular}




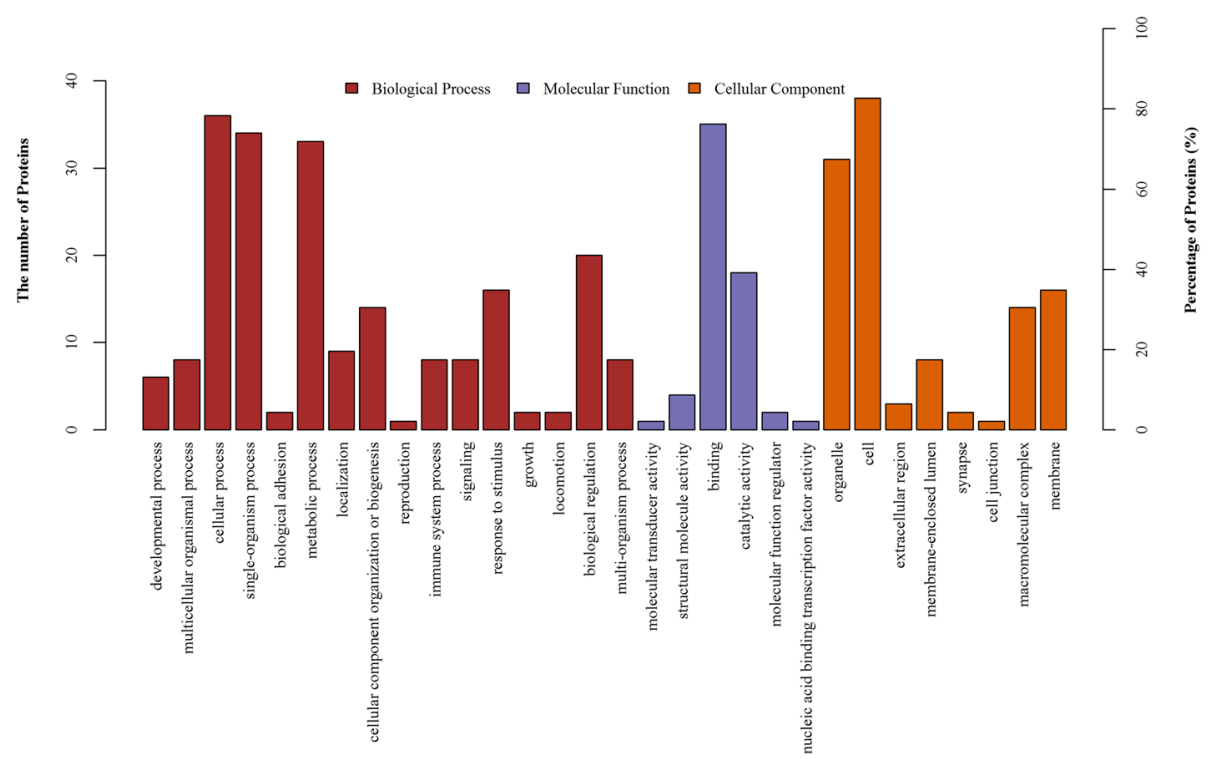

Fig. 2 GO distribution analysis of differentially expressed proteins in hepatic tissues from OG group and LG group. OG, overgrazing; LG, light grazing. The number of proteins for each $\mathrm{GO}$ annotation is shown in right axis, and the proportion of proteins for each $\mathrm{GO}$ annotation is exhibited in left axis

due to the imbalance in protein and fermentable carbohydrates in the herbage [20]. Moreover, lower levels of NEFA and IGF-1 were observed in the OG group, which indicated that fatty acid biosynthesis and anabolic effects in sheep were reduced due to overgrazing [20]. Both above nutrients are very closely related to animal growth.

The liver is an essential nutrient metabolism organ in which, nitrogen compounds metabolism takes a central role. Nitrogen compounds metabolism, including protein metabolism, amino acid metabolism, ammonia toxic elimination and others, can thus be an important indicator of hepatocyte health. [23]. In this study, nearly all six differentially expressed protein species related to protein modification and metabolism were decreased in OG sheep with the exception of KYNU (kynureninase). Among these proteins, KYNU is an enzyme within the tryptophan metabolism pathway [24]. A previous study demonstrated that tryptophan was the third most limiting amino acid in growing lambs, and its inadequate supply or increased catabolism in vivo can trigger limited protein deposition and the elevation of urinary $\mathrm{N}$ excretion [25]. The up-regulation of KYNU was observed in the livers of OG sheep and is consistent with the higher serum level of BUN in the present study. HAL (histidine ammonia-lyase) catalyzes the elimination of ammonia from the substrate to form $(E)$-urocanate

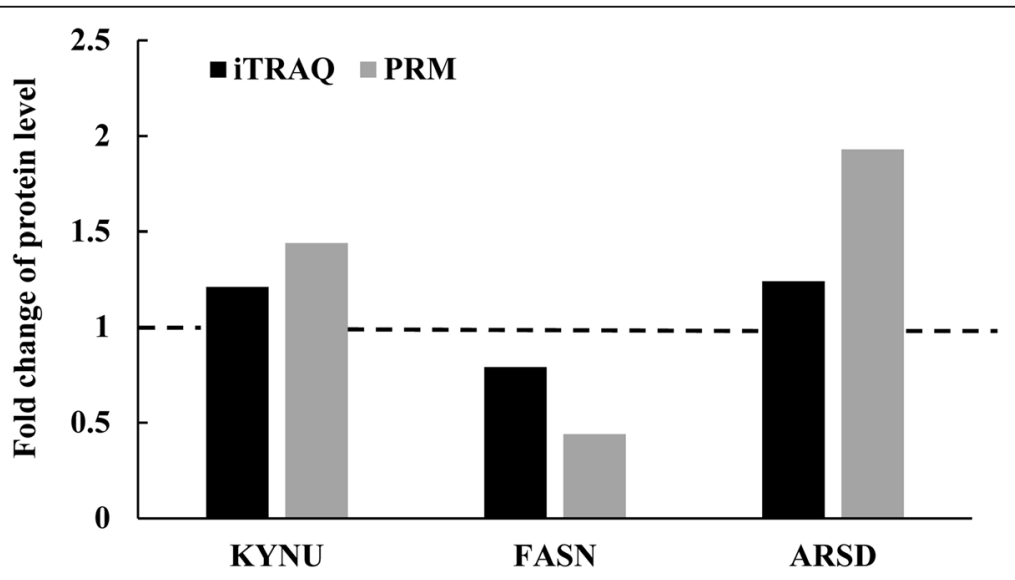

Fig. 3 Expression patterns of selected protein candidates in the hepatic tissue of OG (overgrazing) group compared with LG (light grazing) group using iTRAQ analysis and PRM validation. Fold change of protein levels (the mean value of OG group/the mean value of LG group) of KYNU (kynureninase), FASN (fatty acid synthase) and ARSD (arylsulfatase D) from iTRAQ analysis and PRM validation 
Table 4 Effect of overgrazing on the immune responses and inflammatory cytokines of sheep

\begin{tabular}{lccc}
\hline & \multicolumn{3}{l}{ Groups } \\
\cline { 2 - 4 } & $\mathrm{LG}^{\mathrm{c}}$ & OG $^{\mathrm{d}}$ & $P$ value \\
\hline $\mathrm{IL}-1 \beta(\mathrm{pg} / \mathrm{mL})^{\mathrm{e}}$ & $10.34 \pm 0.72^{\mathrm{b}}$ & $22.90 \pm 3.68^{\mathrm{a}}$ & 0.004 \\
$\mathrm{IL}-4(\mathrm{pg} / \mathrm{mL})^{\mathrm{f}}$ & $21.38 \pm 2.19^{\mathrm{b}}$ & $29.06 \pm 1.43^{\mathrm{a}}$ & 0.007 \\
$\mathrm{IL}-6(\mathrm{pg} / \mathrm{mL})^{\mathrm{g}}$ & $90.61 \pm 22.03^{\mathrm{b}}$ & $222.50 \pm 10.81^{\mathrm{a}}$ & 0.001 \\
$\mathrm{IFN}-\gamma(\mathrm{pg} / \mathrm{mL})^{\mathrm{h}}$ & $30.76 \pm 4.01^{\mathrm{a}}$ & $21.56 \pm 4.18^{\mathrm{b}}$ & 0.050 \\
$\operatorname{lgA}(\mathrm{g} / \mathrm{L})^{\mathrm{i}}$ & $0.73 \pm 0.06^{\mathrm{a}}$ & $0.54 \pm 0.06^{\mathrm{b}}$ & 0.022 \\
$\operatorname{lgG}(\mathrm{g} / \mathrm{L})^{\mathrm{j}}$ & $19.85 \pm 1.95^{\mathrm{a}}$ & $15.19 \pm 1.73^{\mathrm{b}}$ & 0.036 \\
\hline
\end{tabular}

$\mathrm{a}, \mathrm{b}$ Values within a column not sharing a common superscript letter indicate significant difference at $P<0.05$. Numbers are means $\pm \operatorname{SD}$. $(n=6)$

${ }^{c} L G$ light grazing

d $O G$ overgrazing

e $I L-1 \beta$ interleukin-1 $\beta$

${ }^{f}$ IL-4 interleukin-4

${ }^{g}$ IL-6 interleukin-6

h IFN- $\gamma$ interferon- $\gamma$

I $g$ A immunoglobulin A

j IgG immunoglobulin G

[26]. The down-regulation of this protein indicates that overgrazing may result in perturbations in ammonia detoxification in hepatocytes, which can be another reason for the increased concentration of BUN in the OG group. Taken together, the expression changes of KYNU and HAL integrated with the results of serum levels of BUN and GLU indicate that overgrazing triggers a shift in energy resources from carbohydrates to proteins causing poorer nitrogen utilization efficiency. A GO annotation enrichment analysis done in the present study also showed that cellular amino acid catabolic process is overrepresented in the hepatic proteome of sheep due to overgrazing. The down-regulation of the other four proteins involved in protein metabolism, including SEC24D (SEC24 homologue D, COPII coat complex component), THNSL2 (threonine Synthase-Like 2), LOC101117129 (UniProt database accession W5PFC9) and ZFAND2B (Zinc finger, AN1-Type Domain 2B), may reflect reduced protein transport, binding and folding capacity [27-29].

Energy production is one of the key functions of the liver, which participates in a number of physiological processes. However, energy production and mitochondrial function are usually found to be impaired in hepatic dysfunction [30]. PYGB (glycogen phosphorylase, brain form) serves as a glucose metabolism protein and contributes to the regulation of carbohydrate metabolism [31]. CREB3L3 (cAMP-responsive element-binding protein 3-like 3) maintains systemic energy homeostasis throughout the entire body [32]. mTOR (mammalian target of rapamycin) is a central signaling molecule that impacts most cellular functions including energy metabolism promotion [33]. MTHFD1L (methylenetetrahydrofolate dehydrogenase (NADP+ dependent) 1-like) and NEK9 (NIMA-related kinase 9) are ATP binding proteins that are involved in mitochondrial function and DNA replication, respectively [34, 35]. These proteins were both down-regulated in OG sheep, suggesting that overgrazing interferes with energy production and metabolism; this is consistent with the decreased serum GLU level in OG sheep in the present study.

The down-regulated proteins DERL1, a lipid binding protein (UniProt database accession W5P8F9), ESYT1 (extended synaptotagmin-like protein 1) and FASN (fatty acid synthase) are classified as lipid metabolism proteins based on their primary function. Of these proteins, DERL1 is a putative dislocon component in the ER (endoplasmic reticulum) membrane that plays an important role in ApoB secretion [36]; FASN stimulates the de novo synthesis of fatty acids [37]. The downregulation of these proteins implies decreased lipid metabolism in the OG group and is consistent with the finding in this study of a lower serum level of NEFA observed in OG sheep.

The liver is an important immune organ in the body that plays indispensable roles in immune response, apoptosis and inflammatory reactions [38]. In this study, two protein species related to apoptosis were up-regulated in the OG group. TMBIM6 (transmembrane BAX inhibitor motif containing 6) promotes apoptosis in prolonged stress or severe conditions [39]; CCAR2 (cell cycle and apoptosis regulator 2) leads to increased level of p53-mediated apoptosis and DNA damage [40]. The up-regulation of TMBIM6 and CCAR2 indicates that overgrazing may lead to a long-term stressful situation and trigger apoptosis in sheep hepatocytes. Other proteins involved in the immune response, including NT5E (5'-nucleotidase, ecto), PPM1B (protein phosphatase, $\mathrm{Mg}^{2+} / \mathrm{Mn}^{2+}$ dependent, 1B), PSMB10 (proteasome subunit beta 1) and TRIM56 (tripartite motif containing 56), are down-regulated, which suggests that the sheep immunity is suppressed during overgrazing, thus increasing the likelihood of bacterial or viral infection and reduced growth performance [41, 42]. These observations were consistent with the reduced immune organ indexes and serum levels of immunoglobulins and the increased concentrations of inflammatory cytokines in OG sheep. Moreover, the reduced abundance of proteins relevant to stress response and detoxification, including UGT2B7 (UDP-glucuronosyltransferase), an oxidoreductase (UniProt database accession W5PKE4), and TAGLN (transgelin), were observed in the OG group, which indicates that longterm overgrazing may lead to oxidative stress and that it inhibits detoxification in the sheep liver [43, 44].

Cytoskeletal proteins play a crucial role in liver protection and maintaining both the cellular structure and integrity of hepatocytes [45]. In this study, three differential protein species related to the cytoskeleton were downregulated in the livers of OG sheep. VASP (vasodilatorstimulated phosphoprotein) is associated with filamentous 
actin formation and plays a widespread role in cell adhesion and motility [46]. NCKAP1 (NCK-associated protein 1) is an integral membrane protein that regulates actin cytoskeleton organization [47]. SNTB1 (beta-1-syntrophin) is a peripheral membrane protein that is associated with mediating high-density lipoprotein (HDL) metabolism in the liver [48]. This is consistent with the elevated AST and ALT serum levels in the OG group of this study, which may interfere with liver protection and normal hepatocytes structure. Other proteins relevant to cell growth and proliferation, including KANK2 (KN motif and ankyrin repeat domain 2) and IST1 (increased sodium tolerance 1), are also down-regulated and may harm the regeneration of hepatocytes in OG sheep due to overgrazing $[49,50]$. Furthermore, the reduced abundance of proteins involved in transcriptional and translational regulation, including a ribosomal protein (UniProt database accession W5P2A1), ZNF207 (zinc finger protein 207), MRPL3 (mitochondrial ribosomal protein L3), DCPS (decapping enzyme, scavenger) and ribosomal protein L14-like protein, was observed in the OG group, which indicates a decreased capacity for protein metabolism to provide sufficient nutritional nitrogen compounds for growth [51-53].

\section{Conclusions}

In summary, the present proteomic analysis demonstrated that overgrazing leads to differential abundances of a number of hepatic proteins in sheep. The functional groupings of those altered proteins are primarily related to protein metabolism, transcriptional and translational regulation, and immune response. Some of the other proteins are involved in nutrient metabolism (energy and lipid metabolism), stress response, and cellular functions (cell cytoskeleton, cell growth and proliferation). Additionally, biochemical and immune analyses provided sufficient physiological evidence. All results obtained from the present study suggest that overgrazing induces a shift in energy resources from carbohydrates to proteins, causing the impairment of nutrient metabolism (protein and lipid) and immunity, which may be the reasons for the reduced growth in sheep. Future studies will investigate the application of nutritional supplementation to improve the growth performance of sheep in overgrazing conditions.

\section{Methods}

\section{Study area and experimental design}

This study was conducted by the Institute of Grassland Research, Chinese Academy of Agricultural Science, Hohhot in the Xilin River Basin, Inner Mongolia Autonomous Region, China (116 $32^{\prime}$ E, $\left.44^{\circ} 15^{\prime} \mathrm{N}\right)$. There was 8 ha of an experimental site with pasture dominated by three grass species: Leymus chinensis, Stipa krylovii and S. grandis.
A total of 60 Uzhumchin wethers were used in the present study. The sheep were born in summer 2013 and at the initiation of the grazing experiment in June were approximately 24 months old with an average live weight of $31.5 \pm 4.5 \mathrm{~kg}$. Water and minerals in lick stones were provided ad libitum during the grazing experiment.

The duration of the grazing experiment was 90 days from June $10^{\text {th }} 2015$ to September $5^{\text {th }} 2015$. There were a total of 6 plots (1.33 ha per plot) in the experimental site ( 3 plots per each grazing intensity), comprising a light grazing group (4 sheep per plot) and an overgrazing group (16 sheep per plot). Therefore, two different grazing intensities were realized: 3.0 (light grazing, LG) and 12.0 sheep/ha (overgrazing, OG).

Herbage samples were obtained monthly and combined at the end of the grazing experiment for chemical composition analysis. The herbage sample collection method was followed a previous study [6]. All details are described in Additional file 5. The content of CP, gross energy, NFE, NDF, ADF and ADL were determined in the herbage sample following the protocol of a previous study [7].

\section{Data and sample collection}

The live weight of all animals was measured at day 0 and day 90 (end of experiment, after $12 \mathrm{~h}$ of fasting) of the grazing season, and the mean daily gain was calculated. At the termination of the experiment, 2 sheep per plot in both groups $(n=6)$ were randomly chosen for blood collection. Each blood sample was collected from the cervical vein using a sterilized syringe. Sera samples were obtained via centrifugation at $2000 \mathrm{~g}$ for $30 \mathrm{~min}$ at $4{ }^{\circ} \mathrm{C}$, then at $400 \mathrm{~g}$ for $10 \mathrm{~min}$ at $4{ }^{\circ} \mathrm{C}$, and all sera samples were stored at $-80{ }^{\circ} \mathrm{C}$ for further analysis. After blood collection, one sheep per plot $(n=3)$ was slaughtered using standard procedures established by the Chinese Academy of Agricultural Sciences. To calculate the indices of immune organs, the spleen and liver were excised and weighted, respectively. Immune organ indices were calculated as the ratio of organ weight to body weight. Hepatic samples $(\sim 2 \mathrm{~g})$ were then washed with ice cold sterilized PBS, frozen in liquid nitrogen, and stored at $-80{ }^{\circ} \mathrm{C}$ for further proteomic analysis.

\section{Biochemical, immune response and inflammation analyses}

For biochemical, immune response and inflammatory parameters of the serum, the concentration of ALT, AST, TP, BUN, GLU, TG, CHOL, NEFA, IgA and IgG were measured using a fully automatic biochemistry analyser (Hitachi 7020, Tokyo, Japan); IL-1 $\beta$, IL-4, IL-6, IGF-1 and IFN- $\gamma$ were determined using a corresponding diagnostic kit (Nanjing Jiancheng Bioengineering Institute, Nanjing, China) according to the instructions of the manufacturer. 


\section{Hepatic sample preparation and protein extraction}

A total of six hepatic samples (one sheep per plot, three biological replications per group) were collected for protein extraction and subsequent proteomic analysis. Each hepatic sample ( $\sim 0.5 \mathrm{~g}$ ) was ground after being frozen in liquid nitrogen in a Dounce glass grinder. The grinded powder was precipitated with $10 \%$ trichloroacetic acid (TCA) (w/v) and $90 \%$ ice-cold acetone at $-20{ }^{\circ} \mathrm{C}$ for $2 \mathrm{~h}$. The precipitate in the sample was obtained via centrifugation at $20000 \mathrm{~g}$ for $30 \mathrm{~min}$ at $4{ }^{\circ} \mathrm{C}$ and subsequently washed with ice-cold acetone. The precipitate was then lysed in the lysis buffer [8 M urea, $30 \mathrm{mM}$ 4-(2-hydroxyethyl)-1-piperazineethanesulfonic acid (HEPES), $1 \mathrm{mM}$ phenylmethanesulfonyl fluoride (PMSF), $2 \mathrm{mM}$ ethylene diamine tetraacetic acid (EDTA), and $10 \mathrm{mM}$ dithiothreitol (DTT)]. The crude tissue extracts were centrifuged to remove the remaining debris. The tissue lysates were reduced for $1 \mathrm{~h}$ at $37^{\circ} \mathrm{C}$ in a water bath through the addition of $10 \mathrm{mM}$ DTT and then alkylated with for $1 \mathrm{~h}$ with the addition of $55 \mathrm{mM}$ iodoacetamide in the dark. Afterwards, the lysates were precipitated by adding 4 volumes of pre-chilled acetone. The pellets were then washed three times with pre-chilled pure acetone and resuspended in the buffer (50\% TEAB and $0.1 \%$ SDS). The centrifugation was repeated to remove the undissolved pellets. Subsequently, protein quantitation was performed using a Bio-Rad Bradford Protein Assay Kit (Hercules, CA, USA).

\section{iTRAQ experiments}

Each sample was digested with modified sequence grade trypsin (Promega Corporation, Madison, WI) at a 1:30 ratio $\left(3.3 \mu \mathrm{g}\right.$ trypsin: $100 \mu \mathrm{g}$ target) overnight at $37{ }^{\circ} \mathrm{C}$. Each isobaric tag $(114,115,116,117,118$ and 119) (AB Sciex, Framingham, MA, USA) was solubilized in $70 \mu \mathrm{L}$ isopropanol and then added to its respective sample (three biological replications per group). Incubation continued for $2 \mathrm{~h}$ at room temperature. All labelled peptides were pooled together and separated using SCX chromatography. The eluted peptides were dried under a vacuum and analyzed via LC-MS/MS based on Q-Exactive (Thermo Scientific). All detailed procedures are described in Additional file 5.

\section{MS data processing and bioinformatics analysis}

Peptide and protein identifications were analyzed using Proteome Discover 1.4 (Thermo Fisher Scientific) and searched with the Mascot search engine (Matrix Science, London, U.K.; version 2.3.0) against the database Uniprot_Ovis aries_27110_20151123.fasta (Nov 23rd, 2015 with 27,110 protein sequences) with the following parameters: enzyme: trypsin; variable modifications: oxidation $(\mathrm{M})$, gln-pyro-glu (N-term $\mathrm{Q})$, and iTRAQ8plex $(\mathrm{Y})$; fixed modification: carbamidomethyl (C), iTRAQ8plex (N-term), and iTRAQ8plex (K); peptide mass tolerance: \pm
20 ppm; fragment mass tolerance: $0.1 \mathrm{Da}$; maximum missed cleavages: 2 . Identified peptides had an ion score above the threshold of peptide identity in Mascot, and protein identifications were accepted as the false discovery rate $(F D R) \leq 0.01$ in which at least one such unique peptide match was specific for the protein. Median ratio normalization was performed to obtain the quantitative protein ratios. Proteins with a 1.2-fold change or greater $(P$-values $<0.05)$ were considered significant.

The Gene Ontology (GO) distribution for all proteins that were differentially expressed in the hepatic tissue of overgrazed sheep was classified using Blast2GO software (http://www.blast2go.com/). The Database for Annotation, Visualization and Integrated Discovery (DAVID) 6.7 (http://david.abcc.ncifcrf.gov/) and the Kyoto encyclopedia of genes and genomes (KEGG) data base (http://www.genome.jp/kegg/), were used to classify differentially altered proteins in significantly overrepresented pathways and GO terms.

\section{Target analysis by PRM}

Three representing proteins of interest were selected to perform the targeted quantification and verification among all proteins of differential abundance under LG and OG conditions from sheep livers. Samples were analyzed using PRM (Additional file 6: Table S5 for settings), which is applied for proteomic data verification in a number of studies [54,55]. Details of this method are provided in the online Additional file 5.

\section{Statistical analysis}

Statistical analyses were performed with SPSS Statistics 17.0 (SPSS, Inc., Chicago, IL, USA). All results are expressed as the means $\pm \mathrm{SD}$. A group difference was analyzed using Student's $t$ test, and $P<0.05$ was considered significant.

\section{Additional files}

Additional file 1: Table S1. Effect of overgrazing on primary nutritional indexes of herbage. (DOCX $14 \mathrm{~kb}$ )

Additional file 2: Table S2. List of all proteins $(n=2153)$ identified in the study. (XLSX $148 \mathrm{~kb}$ )

Additional file 3: Table S3. List of all differentially expressed proteins $(n=45)$ identified in the study. (XLSX $11 \mathrm{~kb})$

Additional file 4: Table S4. Enrichment analysis of differentially expressed proteins in the hepatic tissue of sheep. (DOCX $15 \mathrm{~kb}$ )

Additional file 5: The detailed description of the experiment methods, including herbage sample collection, SCX chromatography, mass spectrometry, targeted protein quantitation. (DOCX $15 \mathrm{~kb}$ )

Additional file 6: Table S5. Parallel reaction monitoring conditions for targeted natural abundance peptides and isotopically labeled peptide standards. (DOCX $14 \mathrm{~kb}$ )

\section{Abbreviations}

ADF: Acid detergent fibre; ADL: Acid detergent lignin; ALT: Alanine aminotransferase; AST: Aspartate aminotransferase; BUN: Blood urea nitrogen; 
CCAR2: Cell cycle and apoptosis regulator 2; CHOL: Cholesterol; CP: Crude protein; CREB3L3: CAMP-responsive element-binding protein 3-like 3; ESYT1: Extended synaptotagmin-like protein 1; FASN: Fatty acid synthase; GLU: Glucose; HAL: Histidine ammonia-lyase; IGF-1: Insulin-like growth factor 1; iTRAQ: Isobaric tags for relative and absolute quantitation; KYNU: Kynureninase; mTOR: Mammalian target of rapamycin; NDF: Neutral detergent fibre; NEFA: Non-esterified fatty acid; NEK9: NIMA-related kinase 9; NFE: Nitrogen free extract; PRM: Parallel reaction monitoring; PYGB: Glycogen phosphorylase; TG: Triglyceride; TMBIM6: Transmembrane BAX inhibitor motif containing 6; TP: Total protein

\section{Acknowledgements}

This research was funded by the Chinese National Key Basic Research and Development Program (2014CB138804) and the Chinese National Key technology research and development program (2012BAD13B07). Shanghai Applied Protein Technology provided the technical support in ITRAQ proteomic analysis and target protein verification.

\section{Funding}

This research was supported by the Chinese National Key Basic Research and Development Program (No: 2014CB138804) and the Chinese National Key technology research and development program (No: 2012BAD13B07).

\section{Availability of data and materials}

All relevant data are within the paper and its Additional files.

\section{Authors' contributions}

WR, XH and JZ developed and framed the research questions. WR and JZ analyzed proteomics data. $\mathrm{XL}$ and $\mathrm{YD}$ were involved in the analysis of serum biochemical, immune and inflammatory data. YW, ZW, NH, LK, CC and CJ were involved in sample collection. WB and $\mathrm{HG}$ were involved in revising the manuscript. WR and JZ drafted the manuscript. All authors read and approved the final manuscript.

\section{Competing interests}

The authors declare that they have no competing interests.

\section{Consent for publication}

Not applicable.

\section{Ethics approval and consent to participate}

This study was conducted in strict accordance with the Regulations for the Administration of Affairs Concerning Experimental Animals of the State Council of the People's Republic of China. The protocol was approved by the Committee on Experimental Animal Management of the Chinese Academy of Agricultural Sciences.

\section{Author details}

'Key Laboratory of Forage Grass, Ministry of Agriculture, Institute of Grassland Research, Chinese Academy of Agricultural Sciences, Hohhot 010010, Inner Mongolia, China. ${ }^{2}$ NSW Department of Primary Industries, Orange Agricultural Institute, Orange, NSW 2800, Australia. ${ }^{3}$ College of Life Sciences, Inner Mongolia Agricultural University, Hohhot 010019, Inner Mongolia, China.

Received: 25 October 2016 Accepted: 20 December 2016 Published online: 05 January 2017

\section{References}

1. Lin L, Dickhoefer U, Müller K, Wang C, Glindemann T, Hao J, et al. Growth of sheep as affected by grazing system and grazing intensity in the steppe of Inner Mongolia, China. Livest Sci. 2012;144(1-2):140-7.

2. Zuo Z, Zhang M, Gao J, Wen S, Hou P, Gao Y. Allelopathic effects of Artemisia frigida Willd. on growth of pasture grasses in Inner Mongolia, China. Biochem Syst Ecol. 2011;39(4-6):377-83.

3. Lin L, Dickhoefer U, Müller K, Susenbeth A. Grazing behavior of sheep at different stocking rates in the Inner Mongolian steppe, China. Appl Anim Behav Sci. 2011;129(1):36-42.

4. Wang CJ, Tas BM, Glindemann T, Mueller K, Schiborra A, Schoenbach P, et al. Rotational and continuous grazing of sheep in the inner Mongolian steppe of China. J Anim Physiol Anim Nutr. 2009;93(2):245-52.
5. Zhang R, Zhang W, Zuo Z, Li R, Wu J, Gao Y. Inhibition effects of volatile organic compounds from Artemisia frigida Willd. on the pasture grass intake by lambs. Small Ruminant Res. 2014;121(2-3):248-54.

6. Hao J, Dickhoefer U, Lin L, Müller K, Glindemann T, Schönbach P, et al. Effects of rotational and continuous grazing on herbage quality, feed intake and performance of sheep on a semi-arid grassland steppe. Arch Anim Nutr. 2013;67(1):62-76.

7. Glindemanna T, Wang C, Tas B, Schiborrab A, Gierusb M, Taubeb F, et al. Impact of grazing intensity on herbage intake, composition, and digestibility and on live weight gain of sheep on the inner Mongolian steppe. Livest Sci. 2009;124(1-3):142-7.

8. Dickhoefer U, Bösing BM, Hasler M, Hao J, Lin L, Müller K, et al. Animal responses to herbage allowance: forage intake and body weight gain of sheep grazing the inner Mongolian steppe - results of a six-year study. J Anim Sci. 2016;94(5):2059-71.

9. Garcia F, Carrère P, Soussana F, Baumont R. The ability of sheep at different stocking rates to maintain the quality and quantity of their diet during the grazing season. J Agr Sci. 2003;140(1):113-24.

10. Lachica M, Aguilera F. Energy expenditure of walk in grassland for small ruminants. Small Ruminant Res. 2005;59(2-3):105-21.

11. Nemeth E, Baird W, O'Farrelly C. Microanatomy of the liver immune system. Semin Immunopathol. 2009;31(3):333-43.

12. Trauner M, Meier PJ, Boyer JL. Molecular pathogenesis of cholestasis. N Engl J Med. 1998;339(17):1217-27.

13. Laporta J, Rosa GJ, Naya H, Carriquiry M. Liver functional genomics in beef cows on grazing systems: novel genes and pathways revealed. Physiol Genomics. 2014;46(4):138-47.

14. Jiang $X$, Zeng T, Zhang S, Zhang Y. Comparative proteomic and bioinformatic analysis of the effects of a high-grain diet on the hepatic metabolism in lactating dairy goats. PLoS One. 2013;8(11):e80698.

15. Astle J, Ferguson JT, German JB, Harrigan GG, Kelleher NL, Kodadek T, et al. Characterization of proteomic and metabolomic responses to dietary factors and supplements. J Nutr. 2007;137(12):2787-93.

16. Zhang J, Li D. Effect of conjugated linoleic acid on inhibition of prolyl hydroxylase 1 in hearts of mice. Lipids Health Dis. 2012;11:22.

17. Wang J, Li F, Dangott J, Wu Y. Proteomics and its role in nutrition research. J Nutr. 2006;136(7):1759-62.

18. Sherlock L, McKeegan DE, Cheng Z, Wathes CM, Wathes DC. Effects of contact dermatitis on hepatic gene expression in broilers. Br Poult Sci. 2012;53(4):439-52.

19. Zhang J, Li C, Tang X, Lu Q, Sa R, Zhang H. High concentrations of atmospheric ammonia induce alterations in the hepatic proteome of broilers (Gallus gallus): an iTRAQ-based quantitative proteomic analysis. PLoS One. 2015;10(4):e0123596.

20. Kaufmann LD, Dohme-Meier F, Münger A, Bruckmaier RM, van Dorland HA. Metabolism of grazed vs. zero-grazed dairy cows throughout the vegetation period: hepatic and blood plasma parameters. J Anim Physiol Anim Nutr. 2012;96(2):228-36.

21. Akbar H, Grala TM, Vailati Riboni M, Cardoso FC, Verkerk G, McGowan J, et al. Body condition score at calving affects systemic and hepatic transcriptome indicators of inflammation and nutrient metabolism in grazing dairy cows. J Dairy Sci. 2015;98(2):1019-32.

22. Kohn RA, Dinneen MM, Russek-Cohen E. Using blood urea nitrogen to predict nitrogen excretion and efficiency of nitrogen utilization in cattle, sheep, goats, horses, pigs, and rats. J Anim Sci. 2005;83(4):879-89.

23. de Oliveiraa S, Camposb S, Oliveirac C, Britod F, Valadares Filhob C, Detmannb E, et al. Nutrient digestibility, nitrogen metabolism and hepatic function of sheep fed diets containing solvent or expeller castorseed meal treated with calcium hydroxide. Anim Feed Sci Tech. 2010;158(1-2):15-28.

24. Harden JL, Lewis SM, Lish SR, Suárez-Fariñas M, Gareau D, Lentini T, et al. The tryptophan metabolism enzyme L-kynureninase is a novel inflammatory factor in psoriasis and other inflammatory diseases. J Allergy Clin Immunol. 2016;137(6):1830-40

25. Van E Nolte J, Löest CA, Ferreira AV, Waggoner JW, Mathis CP. Limiting amino acids for growing lambs fed a diet low in ruminally undegradable protein. J Anim Sci. 2008;86(10):2627-41.

26. Katona A, Toşa MI, Paizs C, Rétey J. Inhibition of histidine ammonia lyase by heteroaryl-alanines and acrylates. Chem Biodivers. 2006;3(5):502-8.

27. Garbes L, Kim K, Rieß A, Hoyer-Kuhn H, Beleggia F, Bevot A, et al. Mutations in SEC24D, encoding a component of the COPII machinery, cause a syndromic form of osteogenesis imperfecta. Am J Hum Genet. 2015;96(3):432-9. 
28. Mason CC, Hanson RL, Ossowski V, Bian L, Baier LJ, Krakoff J, et al. Bimodal distribution of RNA expression levels in human skeletal muscle tissue. BMC Genomics. 2011;12:98.

29. Glinka T, Alter J, Braunstein I, Tzach L, Wei Sheng C, Geifman S, et al. Signalpeptide-mediated translocation is regulated by a p97-AIRAPL complex. Biochem J. 2014:457(2):253-61.

30. Young TA, Bailey SM, Van Horn CG, Cunningham CC. Chronic ethanol consumption decreases mitochondrial and glycolytic production of ATP in liver. Alcohol Alcohol. 2006;41(3):254-60.

31. Das A, Durrant D, Koka S, Salloum FN, Xi L, Kukreja RC. Mammalian target of rapamycin (mTOR) inhibition with rapamycin improves cardiac function in type 2 diabetic mice: potential role of attenuated oxidative stress and altered contractile protein expression. J Biol Chem. 2014;289(7):4145-60.

32. Nakagawa Y, Satoh A, Yabe S, Furusawa M, Tokushige N, Tezuka H, et al. Hepatic CREB3L3 controls whole-body energy homeostasis and improves obesity and diabetes. Endocrinology. 2014;155(12):4706-19.

33. Laplante M, Sabatini DM. mTOR signaling in growth control and disease. Cell. 2012;149(2):274-93.

34. Momb J, Lewandowski JP, Bryant JD, Fitch R, Surman DR, Vokes SA, et al Deletion of Mthfd1I causes embryonic lethality and neural tube and craniofacial defects in mice. Proc Natl Acad Sci U S A. 2013;110(2):549-54.

35. Smith SC, Petrova AV, Madden MZ, Wang H, Pan Y, Warren MD, et al. A gemcitabine sensitivity screen identifies a role for NEK9 in the replication stress response. Nucleic Acids Res. 2014;42(18):11517-27.

36. Suzuki M, Otsuka T, Ohsaki Y, Cheng J, Taniguchi T, Hashimoto H, et al. Derlin-1 and UBXD8 are engaged in dislocation and degradation of lipidated ApoB-100 at lipid droplets. Mol Biol Cell. 2012;23(5):800-10.

37. Wang Z, Li Q, Chamba Y, Zhang B, Shang P, Zhang H, et al. Identification of genes related to growth and lipid deposition from transcriptome profiles of pig muscle tissue. PLoS One. 2015;10(10):e0141138.

38. Racanelli $V$, Rehermann B. The liver as an immunological organ. Hepatology. 2006:43(2 Suppl 1):S54-62.

39. Robinson KS, Clements A, Williams AC, Berger CN, Frankel G. Bax inhibitor 1 in apoptosis and disease. Oncogene. 2011;30(21):2391-400.

40. Magni M, Ruscica V, Buscemi G, Kim JE, Nachimuthu BT, Fontanella E, et al. Chk2 and REGy-dependent DBC1 regulation in DNA damage induced apoptosis. Nucleic Acids Res. 2014;42(21):13150-60.

41. Stremitzer S, Sunakawa Y, Zhang W, Yang D, Ning Y, Stintzing S, et al. Variations in genes involved in immune response checkpoints and association with outcomes in patients with resected colorectal liver metastases. Pharmacogenomics J. 2015;15(6):521-9.

42. Kasthuri SR, Umasuthan N, Whang I, Lim BS, Jung HB, Oh MJ, et al. Molecular characterization and expressional affirmation of the beta proteasome subunit cluster in rock bream immune defense. Mol Biol Rep. 2014;41(8):5413-27.

43. Jeong HU, Kim JH, Lee DY, Shim HJ, Lee HS. In vitro metabolic pathways of the new anti-diabetic drug evogliptin in human liver preparations. Molecules. 2015;20(12):21802-15.

44. Wang SH, Cheng CY, Tang PC, Chen CF, Chen HH, Lee YP, et al. Differential gene expressions in testes of $L 2$ strain Taiwan country chicken in response to acute heat stress. Theriogenology. 2013;79(2):374-82.

45. Sergi C, Abdualmjid R, Abuetabh Y. Canine liver transplantation model and the intermediate filaments of the cytoskeleton of the hepatocytes. J Biomed Biotechnol. 2012;2012:131324

46. Tu WW, Ji LD, Qian HX, Zhou M, Zhao JS, Xu J. Tributyltin induces disruption of microfilament in HL7702 cells via MAPK-mediated hyperphosphorylation of VASP. Environ Toxicol. 2016;31(11):1530-8.

47. Loo CS, Chen CW, Wang PJ, Chen PY, Lin SY, Khoo KH, et al. Quantitative apical membrane proteomics reveals vasopressin-induced actin dynamics in collecting duct cells. Proc Natl Acad Sci U S A. 2013;110(42):17119-24.

48. Hebel T, Eisinger K, Neumeier M, Rein-Fischboeck L, Pohl R, Meier EM, et al. Lipid abnormalities in alpha/beta2-syntrophin null mice are independent from ABCA1. Biochim Biophys Acta. 2015;1851(5):527-36

49. Gee HY, Zhang F, Ashraf S, Kohl S, Sadowski CE, Vega-Warner V, et al. KANK deficiency leads to podocyte dysfunction and nephrotic syndrome. J Clin Invest. 2015;125(6):2375-84

50. Guo EZ, Xu Z. Distinct mechanisms of recognizing endosomal sorting complex required for transport III (ESCRT-III) protein IST1 by different microtubule interacting and trafficking (MIT) domains. J Biol Chem. 2015; 290(13):8396-408

51. Russo J, Santucci-Pereira J, Russo $1 \mathrm{H}$. The genomic signature of breast cancer prevention. Genes. 2014;5(1):65-83.
52. Galmiche L, Serre V, Beinat M, Assouline Z, Lebre AS, Chretien D, et al. Exome sequencing identifies MRPL3 mutation in mitochondrial cardiomyopathy. Hum Mutat. 2011;32(11):1225-31.

53. Zhou M, Bail S, Plasterer HL, Rusche J, Kiledjian M. DcpS is a transcriptspecific modulator of RNA in mammalian cells. RNA. 2015;21(7):1306-12.

54. Xue T, Liu P, Zhou Y, Liu K, Yang L, Moritz RL, et al. Interleukin-6 induced "Acute" phenotypic microenvironment promotes Th1 anti-tumor immunity in cryo-thermal therapy revealed by shotgun and parallel reaction monitoring proteomics. Theranostics. 2016;6(6):773-94.

55. Mackey KR, Post AF, Mcllvin MR, Cutter GA, John SG, Saito MA. Divergent responses of Atlantic coastal and oceanic Synechococcus to iron limitation. Proc Natl Acad Sci U S A. 2015;112(32):9944-9.

\section{Submit your next manuscript to BioMed Central and we will help you at every step:}

- We accept pre-submission inquiries

- Our selector tool helps you to find the most relevant journal

- We provide round the clock customer support

- Convenient online submission

- Thorough peer review

- Inclusion in PubMed and all major indexing services

- Maximum visibility for your research

Submit your manuscript at www.biomedcentral.com/submit
) Biomed Central 